\title{
Enige opmerkingen over het (nieuwe) erfrecht en nalatenschapsmediation
}

\author{
Prof. dr. mr. G. van der Burght LL.M.*
}

Nadat Nederland in 2003 een geheel nieuw erfrecht had ingevoerd zijn de Caribische landen van het Koninkrijk met een sterk daarmee overeenkomend stelsel gevolgd. Curaçao en Sint Maarten ${ }^{1}$ hebben het inmiddels ingevoerd; Aruba $^{2}$ wacht op het landsbesluit tot invoering. ${ }^{3}$

Hierna treft men enige kanttekeningen aan bij (de keuzes van) het nieuwe erfrecht en enige opmerkingen over het oplossen van erfrechtgeschillen.

\section{Een snippertje nieuw erfrecht en nog in het kort ook!}

Bij bestudering van het nieuwe erfrecht springt direct in het oog de complexe structuur ervan: het is een uniek stelsel met in te roepen wilsrechten, vruchtgebruiken en vruchtgebruikers. Die vruchtgebruiker (what's in a name?) kunnen - met rechterlijke toestemming over het vruchtgebruiksvermogen beschikken en het zelfs verteren; en dat allemaal ten koste van de hoofdgerechtigden (kinderen van de erflater), voor wie immers bij het overlijden van de betrokken ouder slechts niet-gegarandeerde vorderingen in het verschiet liggen.

Ook in het erfrecht heeft Newspeak ${ }^{4}$ haar intrede gedaan.

Meer specifiek valt op dat het nieuwe Caribisch erfrecht voor de afstammelingen geen legitieme portie meer kent en dat verdient hulde. ${ }^{5}$ In dit nieuwe (Nederlands) erfrecht is het

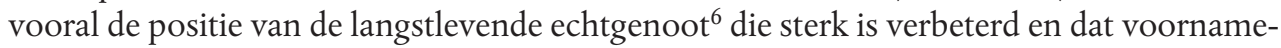
lijk ten detrimente van de kinderen. Gezien de wijze waarop dit is geregeld, naast het

* Prof. dr. mr. G. van der Burght LL.M. is juridisch adviseur en (nalatenschaps)mediator te Bloemendaal en docent aan de opleiding Nalatenschapsmediation; emeritus hoogleraar privaat- en notarieel recht aan de Vrije Universiteit Amsterdam en Familie- en erfrecht aan de Universiteit van de Nederlandse Antillen (thans: University of Curaçao); oud-honorair raadsheer Gerechtshof 's-Gravenhage; medeoprichter en eerste voorzitter Stichting Nalatenschapsmediation.

1 Curaçao, Landsverordening erfrecht en schenking, PB 2011, nr. 68, in werking getreden op 1 januari 2012 en Sint Maarten, Landsverordening erfrecht en schenking, AB 2014, nr. 6, in werking getreden op 1 april 2014.

$2 A B$ 2016, nr. 51.

3 G. van der Burght, Nederlands Caribisch Erfrecht, Oisterwijk: Wolf Publishers 2016.

4 G. Orwell, Nineteen Eighty-Four, Londen: Harvill Secker 1949.

5 In o.m. Pitlo-Van der Burght, Erfrecht, v.a. $5^{\text {e }}$ druk 1977, p. 89 bepleitte ik al de afschaffing van de legitieme: 'dat de legitieme zijn langste tijd behoort te hebben gehad'.

6 Waar over echtgenoot en huwelijk wordt gesproken doelt de auteur voor zover van toepassing tevens op de geregistreerde partner en het geregistreerde partnerschap. 
afschaffen van de legitieme, zou deze benadeling van de kinderen door sommigen misschien wel kunnen beschouwd als een beetje over the top. Eigen bestudering van het erfrecht kan deze constatering schragen; ik ga daar niet verder op in, maar vaststaat dat 'de eeuw van het kind"7 definitief ${ }^{8}$ voorbij is.

In hoeverre het zojuist opgemerkte onverkort geldt voor het Caribisch erfrecht valt echter te bezien.

\subsection{Algemeen}

In alle drie de Caribische landen zijn de ingediende voorstellen voor de landsverordening betreffende het erfrecht van overeenkomstige inhoud. Dit geldt ook voor de memories van toelichting. Het is een en dezelfde auteur $-\mathrm{mr}$. Jan de Boer ${ }^{9}-$ die de drie regeringen ${ }^{10}$ in dezen heeft ondersteund.

De verschillende Staten hebben zonder opvallende amendementen de voorstellen aangenomen. Het heeft er dan ook alle schijn van dat een echte eigen inbreng van de respectieve landelijke politici en van de politieke organen nogal beperkt is geweest.

Eindelijk, na ruim tachtig (80!) jaar strijd, kreeg de langstlevende echtgenoot zijn recht. Immers, pas in 1932 ontving de langstlevende zijn 'kindsdeel'. Tot dan toe moest de familie van de erflater tot in de twaalfde $\left(12^{\mathrm{e}}\right)$ graad zijn uitgestorven, voordat de echtgenoot kon erven.

De weg die heeft geleid tot het realiseren van de gerechtigheid voor de echtgenoot, is grotendeels gelegd door het notariaat met zijn testamentaire constructies; met name inhoudende de 'ouderlijke boedelverdeling'. Het notariaat werd daarin steeds weer gesteund door de Hoge Raad. Deze had de basis voor de ontwikkeling gelegd in de befaamde uitspaak De Visser/Harms. ${ }^{11}$ Dit arrest werd gevolgd door een reeks van stimulerende vonnissen en arresten. Een en ander heeft tot gevolg gehad, dat al ruim vóór de invoering van het nieuwe erfrecht de erflater zijn langstlevende echtgenoot door middel van testamentaire beschikkingen verzorgd kon achterlaten. Succesvolle aanvallen van kinderen op basis van hun legitimaire rechten behoefde deze niet te vrezen.

De aanspraken van de overlevende echtgenoot op de nalatenschap vonden hun beperking in de omvang van diens verzorgingsbehoefte: evenwicht tussen betrokkenen.

Deze ideale uitkomst moest van de Nederlandse politiek door wetgeving kunnen worden bereikt, zonder de noodzaak van testamentair maatwerk. De poging om dit maatwerk - testamenten met ouderlijke boedelverdeling - te vervangen door een systeem dat dit imi-

7 De Zweedse feministe en pedagoge E. Key, De eeuw van het Kind, Stockholm: Barnets Århundrade, Albert Bonniers Förlag 1900; C. Veth, Bonzo en de eeuw van het kind, Bussum: Van Dishoeck 1930, C. Buddingh, De eeuw van het kind, Den Haag: Mikado Pers 1988, Vgl. De Groene Amsterdammer, 30 juni 2001.

8 G. van der Burght in: Meesterlijk groot voor de kleintjes (liber amicorum prof. mr. J.E. Doek), Deventer: Kluwer 2004.

9 Rechter in het Gemeenschappelijk Hof van Justitie van Aruba, Curaçao, Sint Maarten en van Bonaire, Sint Eustatius en Saba.

10 Alsmede de regering van de Republiek Suriname.

11 HR 30 november 1945, NJ 1946/62. 
teert, heeft in Nederland echter niet geleid tot een afname van het aantal testamenten, zoals het streven was. Integendeel, het heeft geleid tot een (nog steeds groeiende) toename ervan, een bloeiende estate-planningpraktijk en een stroom van rechterlijk uitspraken. ${ }^{12}$

\section{Caribisch erfrecht}

\subsection{De langstlevende echtgenoot}

De positie van de langstlevende echtgenoot is in het nieuwe erfrecht aldus verstevigd, doordat deze de enige gerechtigde wordt van alle vermogensbestanddelen van de nalatenschap. ${ }^{13}$ Dit alles op grond van de bepalingen van niet-dwingend recht en dus van regelend recht neergelegd in titel 3 , afdeling 1 van boek 4 BWA. ${ }^{14}$

De kinderen, die formeel wel erfgenaam zijn, verkrijgen naar rato van hun erfportie een vordering op de langstlevende in geld, berekend over het saldo van de nalatenschap. Deze vordering is niet eerder opeisbaar dan bij het overlijden van de langstlevende ouder of bij diens faillissement. Mocht in het eerste geval bij ernstig materialistisch ingestelde kinderen wellicht een hoerastemming kunnen ontstaan, in het laatste geval zeker niet!

Dit systeem van afwikkeling van de nalatenschap heet de 'wettelijke verdeling'. Artikel 3:182 BWA bepaalt 'dat als een verdeling wordt aangemerkt iedere rechtshandeling waartoe alle deelgenoten (...) medewerken en krachtens welke een of meer van hen een of meer goederen der gemeenschap met uitsluiting van de overige deelgenoten verkrijgen'.

Het behoeft weinig toelichting dat de 'wettelijke verdeling' een onjuiste betiteling van het fenomeen van artikel 4:13 e.v. BWA is. Bij eerste lezing van de betrokken wetsbepalingen blijkt al zonneklaar, dat er tussen de langstlevende en de kinderen nooit enige gemeenschap heeft bestaan. Door het overlijden van de erflater verkrijgt de langstlevende van rechtswege - dus zonder het verrichten van rechtshandelingen - alle goederen van de nalatenschap en verkrijgen de kinderen vorderingen op de langstlevende, welke nooit tot het vermogen van de erflater hebben behoord. Beter ware de term: wettelijke verkrijging.

Deze echtelijke voorrangspositie ten opzichte van de kinderen is omvangrijk. Immers, de echtgenoot is goederenrechtelijk gerechtigd tot alle goederen en is volstrekt vrij te beschikken over dat gehele nalatenschapsvermogen, dat hij immers krachtens erfrecht als eigen vermogen heeft verkregen. De kinderen ontvangen op de langstlevende slechts vorderingen die niet voorzien in enige zekerheid dat deze ooit geheel of gedeeltelijk zullen worden voldaan.

12 WODC, Kwaliteit in zware tijd, Den Haag: Boom Juridische uitgevers 2011.

13 Hij is ook de enige die de schulden van de boedel moet voldoen.

14 BWA: omdat het gaat om de wetgeving in de verscheidene Nederlands-Caribische landen, hanteer ik voor de eenvoud BWA(ntiliana); BWC(aribisch) had ook gekund. 


\subsubsection{Beperking}

De bepaling waarin deze voordelige positie voor de echtgenoot is vervat, beperkt in het Caribisch recht echter de reikwijdte van het toepassingsgebied en wijkt hiermee af van het Nederlands erfrecht. ${ }^{15}$ De eerste volzin van artikel 4:13 lid 1 BWA ${ }^{16}$ luidt immers:

'De nalatenschap van de erflater die een echtgenoot en een of meer kinderen die allen tevens kind zijn van de echtgenoot, als erfgenamen achterlaat, wordt, tenzij de erflater bij uiterste wilsbeschikking heeft bepaald dat deze afdeling geheel buiten toepassing blijft, overeenkomstig de volgende leden verdeeld.'

Ik doel dan op het cursieve gedeelte. Ingeval de langstlevende niet de ouder is van alle kinderen van de erflater, geldt artikel 4:13 BWA niet en is er dus géén wettelijke verdeling. In dat geval bestaat tussen de erfgenamen - waaronder de langstlevende - een onverdeelde nalatenschap; alle deelgenoten zullen deze tezamen moeten verdelen conform onder meer de regels van afdeling 4.6.4 BWA en van boek 3 titel 7 BWA.

\subsubsection{Motivering I}

De ratio om anders dan in Nederland in geval van aanwezigheid van één of meer nietgemeenschappelijke ${ }^{17}$ kinderen de wettelijke verdeling niet toe te passen, lezen wij in de memorie van toelichting op de ontwerplandsverordening:

'Naar de mening van ondergetekende gaat dit, mede in aanmerking genomen de dwingendrechtelijke vangnet-bescherming die afdeling 2 al biedt, naar de hier te lande heersende opvattingen te ver...'

Het is jammer, dat de minister niet aangeeft op basis van welk empirisch onderzoek de bevolking van de Caribische landen van oordeel zou zijn, dat de bescherming van de langstlevende ouder te ver zou gaan, indien de erflater ook uit een andere relatie kinderen zou hebben.

De reikwijdte van de oorspronkelijke (Nederlandse) bepaling zorgt ervoor dat de langstlevende niet zal zijn overgeleverd aan de grillen van de kinderen (en vergeet niet: de schoonkinderen). De noodzaak van een dergelijke bescherming geldt, zou ik zeggen, a fortiori indien sprake is van een stiefouder met stiefkinderen.

Veel minder dan wenselijk blijft er dan ook over van het initiatief om gevolg te geven aan de door de minister beschreven opvatting, dat '[s]inds lang de overtuiging bestaat dat de positie van de langstlevende echtgenoot verbetering behoeft'.

15 Art. 4:13 lid 1 Ned. BW: 'De nalatenschap van de erflater die een echtgenoot en een of meer kinderen als erfgenamen achterlaat, wordt, tenzij de erflater bij uiterste wilsbeschikking heeft bepaald dat deze afdeling geheel buiten toepassing blijft, overeenkomstig de volgende leden verdeeld.'

16 Ik bespreek het in Curaçao en Sint Maarten vigerende erfrecht en duidt het daar geldende Burgerlijk Wetboek aan als BWA.

17 Voor het vervolg: ik versta onder 'gemeenschappelijke kinderen' de situatie waarin er uitsluitend kinderen aanwezig zijn die allen van erflater en langstlevende samen zijn. 


\subsubsection{Gewone verdeling}

Een verdeling van een nalatenschap is voor de meeste families een 'groot avontuur'; men leert elkaar in een nieuwe setting kennen en komt terecht in overleggen van een geheel andere aard dan de gebruikelijke. Ter gelegenheid van de afwikkeling van een nalatenschap komen emoties en geld bijeen; vaak vormt de boedelverdeling tevens de gelegenheid om oude rekeningen te vereffenen. In de meest evenwichtige families ziet men, dat boedelverdeling tussen eigen ouder en eigen kinderen leidt tot conflicten tussen de nabestaanden. Verdelingen waarbij alleen eigen kinderen betrokken zijn bieden volop munitie voor een familieruzie en die zal alleen maar meer dreigen, indien er 'vreemde' kinderen paraisseren uit andere al dan niet buitenechtelijke relaties van de erflater en aan de verdelingstafel plaatsnemen. Dit alles biedt een reële kans dat (mede) de positie van de langstlevende onder vuur komt te liggen en zijn beschermde positie illusoir blijkt te zijn. Zie verder onder paragraaf 2.1.4.3 e.v.

\subsubsection{Motivering II}

Ook als motief voor de beschreven beperking van artikel 4:13 BWA voert de minister aan dat de naar zijn mening 'royale Nederlandse bescherming' niet op zijn plaats is

'indien de langstlevende stiefouder - die even oud of zelfs jonger kan zijn dan de kinderen van de erflater - aan de wettelijke verdeling van afdeling 1 geen werkelijke behoefte heeft.'

Ik merk op, dat ook indien er slechts gemeenschappelijke kinderen zijn, het feit blijft bestaan dat op een echtgenoot die zelf 'loaded' is de wettelijke verdeling van toepassing is, tenzij de erflater bij testament anders heeft beslist. ${ }^{18}$ Dat dit feit zoveel ernstiger zou zijn ingeval de langstlevende een ander is dan de ouder van alle kinderen zie ik niet.

\subsubsection{1 'Te' jonge echtgenoot}

Wel kan ik de minister volgen in het geval deze nieuwe echtgenoot aanzienlijk jonger is dan de erflater of even oud of zelfs jonger is dan de kinderen van laatstgenoemde. De kans dat die kinderen ooit nog iets van het vermogen van hun eerst-overleden ouder zullen verkrijgen kan dan wel vergeten worden. De minister heeft hier 'slechts' het oog op de specifieke situatie van die te jeugdige echtgenoot. Deze specifieke omstandigheid verdient - indien men dat wenst - een specifieke daarop gerichte legislatieve oplossing. Het thans ingezette instrument - algemeen geldende beperking van de reikwijdte van het toepassingsgebied van de wettelijke verdeling - veroorzaakt onnodig veel 'collateral damage'.

18 S. Perrick, Het belang van conservatoir beslag ter verzekering van niet opeisbare erfrechtelijke vorderingen, Tijdschrift Erfrecht 2016, afl. 5 doet een poging aan te tonen dat ingeval door een wettelijke verdeling de langstlevende meer verkrijgt dan zijn verzorgingsbehoefte vordert, de kinderen conservatoir beslag kunnen leggen ter verzekering van hun niet-opeisbare vordering. 
Het probleem van de 'te' jonge nieuwe echtgenoot bevindt zich in het gezelschap van de kwestie en discussie rond de destijds bestaande Lex Hac edictali. ${ }^{19}$ Deze, reeds decennia geleden afgeschafte, regeling bevatte een beperking van het erfrecht van de tweede (en volgende) echtgeno(o)t(en) ten opzichte van de kinderen uit een eerder huwelijk van de erflater. In die discussie stelde men tegenover elkaar de bekende oude bok en het groene blaadje dan wel de golddigger enerzijds en anderzijds de jonge vrouw, die de man-met-jonge-kinderen betrekkelijk direct nadat deze weduwnaar was geworden ondersteunde en uiteindelijke met hem trouwde. Als een eigen moeder zorgde zij voor de kinderen en als een trouwe echtgenote voor de man tot aan diens overlijden.

\subsubsection{Suriname: gemiste kans}

Aanvankelijk bevatte het voorgestelde nieuwe erfrecht van Suriname ${ }^{20}$ een evenwichtiger regeling ter bestrijding van dit door de minister ontwaarde gevaar van een ten opzichte van erflaters kinderen te jeugdige leeftijd van de nieuwe echtgenoot. Dit voorstel hield in artikel 4:13 lid 1 Voorstel Sur. BW in:

'De nalatenschap van de erflater die een echtgenoot en een of meer kinderen als erfgenamen achterlaat, wordt, mits voor alle kinderen geldt dat zij tevens kind zijn van de echtgenoot of meer dan twintig jaren jonger zijn dan de echtgenoot, overeenkomstig de volgende leden verdeeld (...).'

Een dergelijke bepaling attaqueerde het probleem met de vereiste precisie, zonder andere langstlevenden te treffen. Echter, bij het laatste ontwerp d.d. 1 maart 2017 heeft de ontwerper zonder toelichting de zinsnede 'of meer dan twintig jaren jonger zijn dan de echtgenoot' helaas laten vervallen

\subsubsection{Niet alleen bij hertouwen}

Het lijkt er wel op alsof de ontwerper van het Caribisch erfrecht zich in artikel 4:13 BWA vooral gericht heeft op deze situatie: de erflater met kinderen uit zijn eerdere huwelijk is hertrouwd; hierdoor zijn bij zijn overlijden niet-gemeenschappelijke kinderen aanwezig die geconfronteerd worden met een stiefouder.

Er bestaan daarnaast echter tal van andere oorzaken waardoor niet-gemeenschappelijke kinderen ${ }^{21}$ aanwezig kunnen zijn, welk feit tot gevolg heeft dat toepassing van de wettelijke verdeling is uitgesloten:

1 de erflater had voor zijn eerste huwelijk al buitenechtelijke kinderen: zie 5 en 6;

2 de erflater heeft tijdens huwelijk kinderen bij een andere vrouw verwekt: zie 5 en 6;

19 Afgeschaft in Nederland in 1970, Pitlo-Van der Burght, Erfrecht (9e druk), nr. 28, Deventer: Kluwer 1997; A.E. Schouten, Het beginsel der Lex Hac Edictali in het Burgerlijk Wetboek (diss Utrecht) 1902; D. De Ruysscher \& E. Alofs (red.), Het nieuw samengesteld gezin: recht en geschiedenis: Blended families: law and history. Antwerpen: Maklu 2014.

20 Met dank aan de redactie van het CJB voor de nieuwe tekst.

21 Het percentage kinderen dat buiten huwelijk is geboren ligt sinds 2010 tussen de 60 en $65 \%$. 
3 de erflater heeft om hem moverende redenen kinderen voor zijn huwelijk bij een andere vrouw erkend; de echtgenote of de (gemeenschappelijke) kinderen van de erkenner kan/kunnen de erkenning niet aanvechten; artikel 1:205 BWA;

4 de erflater heeft om hem moverende redenen tijdens zijn huwelijk kinderen bij een andere vrouw erkend; de echtgenote of de (gemeenschappelijke) kinderen van de erkenner kan/kunnen de erkenning niet aanvechten; artikel 1:205 BWA;

5 niet-erkende door de erflater verwekte kinderen slagen tijdens diens leven in een vaderschapsactie conform artikel 1:207 BWA;

6 niet-erkende door de erflater verwekte kinderen slagen na diens overlijden in een vaderschapsactie conform artikel 1:207 BWA. Uitzonderingen: de rechter beperkt op grond van artikel 1:207a lid 1 BWA de erfrechtelijke gevolgen dan wel de actie wordt langer dan viff jaar na het overlijden van de erflater ingesteld; artikel 1:207a lid 2 BWA.

\subsubsection{Escape?}

In al deze gevallen is de langstlevende echtgenoot verstoken van de toepassing van titel 3 , afdeling 1, tenzij de erflater bij testament anders beschikt. Aldus de slotzin van artikel 4:13 lid 1 BWA: 'Bij uiterste wilsbeschikking kan de erflater bepalen dat deze afdeling toepasselijk is ongeacht of zijn kinderen tevens kind zijn van de echtgenoot.' Bij deze 'escape' lopen wij aan tegen hetgeen de minister meedeelt in de memorie van toelichting: 'Ook is van belang dat hier te lande minder dan in Nederland testamenten worden gemaakt.' Bij de huidige stand van zaken kan vanuit de testamentaire hoek dus weinig soelaas voor de betrokken langstlevende echtgenoot worden verwacht. ${ }^{22}$ Waarom dan toch die keuze?

\subsubsection{Motivering III}

Als motivering om bij aanwezigheid van niet-gemeenschappelijk kinderen de wettelijke verdeling niet toe te passen voert de minister tevens het volgende aan:

'Van hen [de niet-gemeenschappelijke kinderen; toev. GvdB] kan niet worden verlangd dat zij voorlopig (tot de dood van de langstlevende echtgenoot) genoegen nemen met een vordering op de langstlevende echtgenoot aan wie zij niet verwant zijn.'

Het eerste deel van deze argumentatie lijkt op zichzelf gedegen. In relatie tot de overige regelingen in het erfrecht blijkt echter deze 'voorkeursbehandeling' van de niet-gemeenschappelijke kinderen als extreem gunstig uit te pakken ten opzichte van de positie van de kinderen in een nalatenschap waarin naast de echtgenoot uitsluitend gemeenschappelijke kinderen competeren.

\subsubsection{Common kids bite the dust}

1 De gemeenschappelijke kinderen moeten het zich laten welgevallen dat de langstlevende alle nalatenschapsvermogen verkrijgt en zij slechts een niet-opeisbare 
vordering. Deze vordering is op geen enkele wijze gesecuriseerd en draagt een verwaarloosbare rente, ${ }^{23}$ namelijk de wettelijke rente minus $6 \%$.

2 De langstlevende echtgenoot behoudt ook bij hertrouwen dit vermogen. Het staat hem vrij dit vermogen te laten vallen in de door dit nieuwe huwelijk ontstane huwelijksgemeenschap met de nieuwe echtgenoot.

3 De aangifte van het voorgenomen huwelijk biedt voor die kinderen een betrekkelijke mogelijkheid hun rechten veilig te stellen. Zij kunnen immers een wilsrecht inroepen; zie artikel 4:19 e.v. BWA.

\subsubsection{Wilsrechten}

Op grond van de inroeping van dat wilsrecht, verkrijgt het gemeenschappelijke kind de blote eigendom van door hem in overleg met de langstlevende (en eventueel met de andere kinderen) gekozen goederen uit de nalatenschap en/of de ontbonden huwelijksgemeenschap die tussen de erflater en de langstlevende heeft bestaan. De volle eigendom van de betrokken goederen verkrijgen de kinderen als het vruchtgebruik van de langstlevende eindigt door en bij zijn overlijden. Een dergelijke blote eigendom heeft waarde als het onroerende zaken of andere registergoederen betreft en mogelijk ook bij een effectenportefeuille. Een blote eigendom van andere goederen - roerende zaken zoals meubelen, muziekinstrumenten, auto's enzovoort - heeft weinig of geen waarde: vaak zullen zij bij het verscheiden van de langstlevende versleten of te gedateerd zijn om nog voldoende waarde te kunnen vertegenwoordigen.

\subsubsection{Belang van de langstlevende?}

Daarentegen lijkt in de verhouding tussen de niet-gemeenschappelijke kinderen en de langstlevende, het belang van de laatste geheel uit het oog te zijn verloren. Of is dat slechts schijn? Immers, zo schrijft de minister: 'Bij dit alles blijft cruciaal dat de dwingendrechtelijke afdeling 2 aan de langstlevende echtgenoot voldoende bescherming biedt (ten koste van alle kinderen).' De minister doelt hier op de regeling van de 'Wettelijke rechten'. ${ }^{24}$

\subsubsection{Wettelijke rechten}

De minister wijst op hetgeen artikel 4:28 e.v. BWA de langstlevende te bieden hebben. Het betreft het voorgezette gebruik van de woning en inboedel voor negen maanden (art. 4:28 BWA). ${ }^{25}$ Voorts het vruchtgebruik van de echtelijke woning en de inboedel, hetgeen de rechter veelal zal toekennen omdat wordt verondersteld dat de langstlevende daar

23 Art. 4:13 lid 4 BWA: 'De in het derde lid bedoelde geldsom wordt, tenzij de erflater, dan wel de echtgenoot en het kind tezamen, anders hebben bepaald, vermeerderd met een percentage dat overeenkomt met dat van de wettelijke rente, voor zover dit percentage hoger is dan zes, berekend per jaar vanaf de dag waarop de nalatenschap is opengevallen, bij welke berekening telkens uitsluitend de hoofdsom in aanmerking wordt genomen.'

24 In het Nederlands BW heten zij de 'Andere Wettelijke rechten'; 'andere', namelijk naast het wettelijke recht bij uitstek: de legitieme.

25 Art. 4:28 lid 1 BWA: 'Indien de woning die de echtgenoot van de erflater bij diens overlijden bewoont, tot de nalatenschap of de ontbonden huwelijksgemeenschap behoort of de erflater ten gebruike toekwam, is de echtgenoot jegens de erfgenamen bevoegd tot voortzetting van de bewoning gedurende een termijn van negen maanden onder gelijke voorwaarden als tevoren. De echtgenoot is op gelijke wijze en voor gelijke duur bevoegd tot voortzetting van het gebruik van de inboedel, voor zover die tot de nalatenschap of de ontbonden huwelijksgemeenschap behoort of de erflater ten gebruike toekwam.' 
behoefte aan heeft; artikel 4:29 BWA. ${ }^{26}$ En ten slotte het vruchtgebruik van de gehele of van een gedeelte van de nalatenschapsgoederen ter verzorging van de langstlevende; ${ }^{27}$ artikel 4:30 BWA. ${ }^{28}$

Voor het verkrijgen van deze rechten is in alle gevallen unanieme feitelijke en juridische medewerking van de kinderen noodzakelijk. Weigeren zij die medewerking, dan zal de overlevende echtgenoot moeten procederen bij het Gerecht in Eerste Aanleg, met alle daarmee verbonden kosten voor alle betrokken partijen en de overheid.

\subsubsection{Voldoende bescherming?}

Is hier nu sprake van 'voldoende bescherming' voor de langstlevende echtgenoot, die in een redelijke verhouding staat tot de positie van de niet-gemeenschappelijke kinderen? Juist waar het gaat om kinderen die 'niet verwant' zijn is de kans reëel dat zij, omdat zij geen of minder emotionele gevoelens jegens de weduwe of weduwnaar koesteren, het op een procedure zullen laten aankomen: deze kinderen hebben niets of weinig te verliezen. Ingeval de langstlevende genoodzaakt is de kinderen in een procedure te betrekken, zal de familierelatie onherstelbare schade oplopen. Ook dit neveneffect zou de wetgever in zijn in de overwegingen (hebben) moeten betrekken. Heeft de minister de theorie in dezen niet te veel laten zegevieren boven de werkelijkheid van de praktijk?

\subsubsection{Kortom, een voorstel!}

Al met al stel ik vast dat het Nederlands Caribisch erfrecht de positie van de langstlevende echtgenoot maar heel matig heeft verstevigd en zeker niet het resultaat behaalt dat de, in de nieuwe wet uitgesloten, ouderlijke boedelverdeling kon bereiken.

Een wijzing van artikel 4:13 BWA conform het helaas inmiddels ingetrokken Surinaamse model zou naar mijn oordeel raadzaam zijn. Derhalve: toepassing van de wettelijke verdeling indien de erflater een echtgenoot en één of meer kinderen als erfgenamen achterlaat, mits alle kinderen tevens kind zijn van de echtgenoot dan wel meer dan twintig jaren jonger zijn dan de echtgenoot.

26 Art. 4:29 lid 1 BWA: 'Voor zover de echtgenoot van de erflater tengevolge van uiterste wilsbeschikkingen van de erflater of doordat de kinderen van de erflater niet tevens kind zijn van de echtgenoot, niet of niet enig rechthebbende is op de tot de nalatenschap van de erflater behorende woning, die ten tijde van het overlijden door de erflater en zijn echtgenoot tezamen of door de echtgenoot alleen bewoond werd, of op de tot de nalatenschap behorende inboedel daarvan, zijn de erfgenamen verplicht tot medewerking aan de vestiging van een vruchtgebruik op die woning en die inboedel ten behoeve van de echtgenoot, voor zover deze dit van hen verlangt.'

27 Alsmede voor de 'sommen ineens'; zie art. 4:35 BWA.

28 Art. 4:30 lid 1 BWA: 'De erfgenamen zijn verplicht tot medewerking aan de vestiging van een vruchtgebruik op andere goederen van de nalatenschap dan bedoeld in artikel 29 ten behoeve van de echtgenoot van de erflater, voor zover de echtgenoot daaraan, de omstandigheden in aanmerking genomen, voor zijn verzorging - daaronder begrepen de nakoming van de overeenkomstig artikel 35, tweede lid, op hem rustende verplichtingen - behoefte heeft en die medewerking van hen verlangt.' 


\section{Andere punten}

Het zal niet verbazen, dat er meer punten zijn die bespreking verdienen.

\subsection{Concubine en concubijn}

Artikel 4:30b BWA handelt over de erfrechtelijke positie van de concubine en de concubijn.

'Heeft de erflater onmiddellijk voorafgaande aan zijn overlijden tien jaren of langer samengeleefd met een ander als waren zij gehuwd, dan kan de rechter, indien dat redelijk is, bepalen dat de ander voor de toepassing van deze afdeling met een echtgenoot gelijkgesteld wordt.'

Op zichzelf een mooie progressief ogende bepaling. Het voorschrift kan leiden tot pittige conflicten en procedures tussen (potentiële) erfgenamen en de vriend of vriendin van de overledene.

Anders dan in Curaçao en Sint Maarten bevat het Arubaanse artikel 4:30b BWA geen tweede lid. In de andere landen luidt dat:

'2. Heeft de erflater een echtgenoot achtergelaten, dan is deze afdeling zowel op de echtgenoot als op de op grond van het eerste lid met een echtgenoot gelijkgestelde persoon van toepassing.'

Door toepassing van lid 2 in de praktijk kan 'thai-boxing for ladies' een theekransje blijken te zijn! Echter, het niet opnemen van dit tweede lid in het BW van Aruba, brengt geen wijziging in de feitelijke situatie: wat te doen als er een wettige en een buitenwettige geliefde is? Dan zal in voorkomende gevallen de rechter de kwestie moeten oplossen. Of hij bevoegd is zonder uitdrukkelijke wetsbepaling ook 'deze afdeling' voor de concubine van toepassing te verklaren, lijkt mij lijkt hoogst discutabel.

De opmerking in de memorie van toelichting dat in Nederland een dergelijke bepaling ontbreekt, is in deze weinigzeggend:

'In Nederland wordt wel de geregistreerde partner gelijkgesteld met een echtgenoot, zowel wat betreft afdeling 1 (de wettelijke verdeling) als afdeling 2 (verzorgingsvruchtgebruik), maar het instituut van geregistreerd partnerschap bestaat niet in de wetgeving hier te lande.'

Immers, conform het Nederlands BW kan naast een huwelijk geen geregistreerd partnerschap met een derde bestaan ${ }^{29}$ en bestaat er dus evenmin concurrentie tussen een echtgenoot en een geregistreerde partner. 


\subsection{Rekbare termijnen}

Artikel 4:40a BWA geeft de rechter de mogelijkheid op verzoek van een belanghebbende een aantal termijnen in het erfrecht te verlengen, 'ook na het verstrijken daarvan'.

De termijnen in het Nederlands erfrecht zijn zeer strak en sommige zijn ontegenzeggelijk onredelijk kort. Waar dan ook terecht kritiek op is. Zeker ook het gegeven dat sommige termijnen niet kunnen worden verlengd of gestuit, maakt dat bedoelde termijnen onnodig knellend zijn.

Met de soepelheid die de Caribische wetgever van het erfrecht biedt om termijnen te verlengen, slaat deze echter door naar het andere uiterste van het spectrum. Hierbij dringt de vraag zich op naar wat het nut nog is van een dergelijke termijn. Hoe kunnen derden of mededeelgenoten afgaan op gedragingen of stilzitten van een (andere) gerechtigde(n)? Tast artikel 4:40a BWA niet het fundamentele doel aan van de termijnen, namelijk het bieden van rechtszekerheid? Waar blijft het houvast voor derden? En wat is de relatie met verjaringstermijnen? Maar bovenal: wat is de leidraad voor de rechter om willekeur en rechtsonzekerheid te voorkomen? Het ware beter geweest als de Caribische wetgever de termijnen (aanzienlijk) had verlengd in plaats van het doel van de termijnstelling te ondergraven.

\section{Heroverweging}

Mocht de Caribische wetgever het nieuwe erfrecht nog eens onder de loep nemen, dan zouden de onder 2 en 3 vermelde onderwerpen in aanmerking komen voor heroverweging.

\section{Nalatenschapsmediation}

\subsection{Vermogen speelt niet de hoofdrol}

Door het overlijden gaan familiale, relationele en andere psychologische en sociologische elementen luid de toon zetten. Vermogenskwesties fungeren dan vaak als trigger of katalysator voor de lancering van gevoelens, discussies en conflicten, maar veel meer vormen die kwesties een dekmantel voor het presenteren van de emotionele rekening aan de ander.

Bij de 'simpele' familieverhoudingen leidt een overlijden tot reflectie bij de nabestaanden. Men gaat zich bewust of onbewust bezinnen op de thans fysiek afgesloten relatie met de overledene. Maar ook veel breder: men wordt zich bewuster van de bestaande gezins- en familieverbanden en de onlosmakelijk samenhangende verhoudingen tussen de overledene, de betrokken persoon en de andere leden van de groep, alles in hun onderlinge wisselwerking.

\subsection{Vragen, vragen, vragen}

Vooral bij het overlijden van de laatste ouder gaan de kinderen ongewild over tot een mentale afsluiting van hun ouder-kindrelatie. Het kind-zijn wordt afgesloten en het kind maakt de eindafrekening op met deze ouder en met de eerder overleden ouder: was dit het dan? Was dit het wat mijn vader of moeder mij of de ander gunde? En waarom ik dit en mijn zus 
of broer dat andere? Waarom heeft mijn moeder of vader die keuze gemaakt? Kreeg ik dat van hem/haar mee voor mijn leven en waarom niet meer of iets anders? Mijn vader/moeder wist toch dat ik meer nodig had dan zij mij nu nalaten?

Niet zelden gaat men zich meer dan anders verdiepen in de familiehistorie. Feiten openbaren zich, variërend van vader had vroeger een relatie met $\mathrm{X}$ tot aan echte familiegeheimen: er blijkt een halfzus/halfbroer rond te lopen. De verhoudingen worden explosief, zeker als dit feit slechts enkele gezinsleden onbekend was. De laatsten voelen zich alsnog buitengesloten; het vertrouwen is geschonden. Het 'nieuwe kind' heeft erfrechtelijke aanspraken en die vormen een bron van extra spanningen.

Hoe dat ook: na het overlijden van de laatste ouder komt de verhouding tot de andere gezinsleden in een ander daglicht te staan: niet meer als zus/broer-deel-van-het-gezin, maar als een zelfstandige persoon, zij het met een gezinsverleden. En al gauw gaat men over tot het vereffenen van (zelfbedachte?) openstaande rekeningen.

\subsection{Verschillende afstammelingen en stiefkinderen}

Het vorenstaande ziet men in veel varianten gebeuren bij het overlijden in traditionele gezinnen die bestonden uit vader en moeder plus de gemeenschappelijke kinderen. De zogenoemde samengestelde gezinnen met kinderen uit verschillende relaties, maar zeker de aanwezigheid van afstammelingen die nooit deel hebben uitgemaakt van het gezin van de erflater vormen het recept voor hevige emoties en conflicten. Tel daarbij op de mogelijke aanwezigheid van stiefkinderen; zij spelen zuiver juridisch niet mee, maar de menselijke werkelijkheid is veel meeromvattend dan de juridische. De gevoelens tussen de gezinsleden ontwikkelen zich vrij en ongebonden en zo ontstaan ook verwachtingen over en weer. Die verwachtingen strekken zich vaak uit tot over het graf. Het kan dan wel zo zijn dat een stiefkind juridisch geen aanspraken kan doen gelden, maar die mag het - emotioneel - zeker wel hebben. Sterker nog: er kunnen situaties zijn waarin het kind ook moreel gezien een aanspraak heeft. ${ }^{30}$

De oorzaken van mogelijke familieravages zijn hiervoor geschetst, en hoe nu verder?

\subsection{Rechter vaak ontoereikend}

Al gauw denkt men dat de erfenisconflicten maar door de rechter moeten worden opgelost. Die reactie is begrijpelijk, maar helaas niet erg adequaat. Immers, in beginsel houdt de rechter zich nagenoeg alleen bezig met juridische zaken: wat zegt de wet en de rechtspraak over de voorgelegde kwestie? We hebben echter gezien dat het juridische aspect slechts één onderdeel van deze familieconflicten vormt. Een rechterlijke uitspraak lost hoogstens dat onderdeel op. Die oplossing brengt tussen partijen echter zelden of nooit vrede. De verhoudingen blijven verstoord. Sterker nog, meer dan eens heeft een rechterlijke uitspraak een permanente breuk ten gevolge: een partij (of soms beide partijen) ziet zich in het ongelijk gesteld, terwijl men er overtuigd van was het gelijk aan zijn zijde te hebben. Een juridisch gelijk en ongelijk is dan ook vaak als olie op het vuur. De familie ligt uiteen en 
derden zullen vaak hun positie gaan innemen: een sociaal weefsel van familie, vrienden en kennissen rafelt.

\subsection{Rechter is buitenstaander}

Bij een beroep op de rechter - ook al gaat het 'slechts' om het juridische geschil - laat men het probleem oplossen door een vreemde derde: een buitenstaander met zijn eigen persoonlijkheid en geschiedenis. ${ }^{31}$ Om het beeld wat gechargeerd te schetsen: de rechter wordt gevoed met informatie afkomstig van twee (al dan niet bewust) bevooroordeelde partijen. Immers, het zijn hun respectieve zienswijzen op de zaak. Hun respectieve advocaten 'vertalen' die op hun eigen wijze, met accenten die deze respectieve advocaten van belang achten en zij verschaffen die informatie aan de rechter. Met andere woorden: de rechter krijgt selectieve informatie. Op basis daarvan moet hij oordelen.

\subsection{Brede diepgaande conflictoplossing}

Conflicten in de relationele sfeer, zoals bij de afwikkeling van een nalatenschap, verdienen een veel bredere aanpak. Immers, zoals gezien vormt de juridische component slechts een relatief klein onderdeel van het totale conflict. Om het conflict op te lossen moet men diep ingaan op de onder het juridische geschil liggende spanningen en geschillen: de persoonlijke gevoelens, woede, teleurstelling, misverstanden, schending van vertrouwen en al het oud zeer moeten volle aandacht krijgen. De betrokken partijen moeten zich bewust worden van de context van hun geschillen: van de rol die ieder in wisselwerking speelt en van de rol die ieder in het gezinsverband had/heeft. De mechanismen die ertoe leiden dat de ene partij zus en de ander zo reageert, moeten door betrokkenen herkend worden. Dan begrijpt men zijn eigen denkraam en reacties en ontstaat er als het goed is ook begrip voor de reacties van de ander.

Voor scheidingen kan een dergelijk resultaat bereikt worden als men bereid is om open met de ander in een scheidingsmediation te gaan. Een goed toegeruste mediator kan partijen over het grillige pad van de emoties leiden en hen helpen bij het zelf vinden van een voor beiden bevredigende beëindiging van de geschillen.

\subsection{Partijen nemen heft in eigen handen: nalatenschapsmediation ${ }^{32}$}

Voor erfenisconflicten heeft de zogenoemde nalatenschapsmediation een aanpak die kan voorkomen dat families blijvend uit elkaar vallen en die bovendien kan helpen in het vinden van een voor allen bevredigende juridische oplossing.

\subsubsection{Wat is (nalatenschaps)mediation?}

Mediation 'is een vorm van bemiddeling in conflicten waarbij een neutrale bemiddelingsdeskundige, de mediator, de onderhandelingen tussen partijen begeleidt teneinde vanuit hun werkelijke belangen tot gezamenlijk gedragen en voor ieder van hen optimale resultaten te komen'.33

31 Vgl. M. Yzermans, De overtuigingskracht van emoties bij het rechterlijk oordeel (diss. Tilburg), Den Haag: Boom Juridische uitgevers 2011.

32 http://nalatenschapsmediation.com/

33 A.F.M Brenninkmeijer e.a., Handboek Mediation (6 druk), Den Haag: Sdu Uitgevers 2017. 
Mediation is een apart vak waarover nogal wat misverstanden bestaan. De mediator begeleidt partijen; hij kan hen inspireren bij het door hen zelf vinden van oplossingen. Hij neemt zeker geen bindende beslissingen voor partijen: dat is de grootste doodzonde van de mediator en tast het wezen van de mediation aan.

Een bekend misverstand is (en was tot voor kort ook in Nederland), dat de notaris als een soort mediator functioneert. De notaris is echter de functionaris die relateert wat partijen overeenkomen. Hij werkt met partijen die het met elkaar (nagenoeg) eens zijn. De notaris mist de opleiding, kennis en vaardigheid om ruziënde partijen tot elkaar te brengen. Dat wil niet zeggen dat sommige notarissen dit wel voor elkaar krijgen, maar dat is niet hun corebusiness, evenmin als dat van de politieagent die een burenruzie helpt oplossen. Dit is ook de visie van de KNB. ${ }^{34}$ (Nederlandse) notarissen die tevens geschillen willen oplossen volgen dan ook mediationopleidingen. ${ }^{35}$

Mediation tussen slechts twee of drie partijen is aanzienlijk eenvoudiger dan nalatenschapsconflicten. Bij deze laatste conflicten spelen familie- en andere relationele verhoudingen en vaak verre historie een belangrijke rol. De probleemanalyse eist onder meer een systemische aanpak met familieopstellingen. ${ }^{36}$ Ervaren mediators kunnen door het volgen van de specialisatie kopstudie nalatenschapsmediation ${ }^{37}$ en het succesvol afleggen van het eraan verbonden examen als Gecertificeerd Nalatenschapsmediator ${ }^{38}$ aan de slag gaan.

\subsubsection{Zelfdoen}

Primair is het van belang dat de betrokkenen zelf (!) bereid zijn met elkaar in gesprek te gaan en openstaan voor een oplossing. De mediator kan met zijn vaardigheden vaak ook de 'meest gesloten' figuren aan het praten krijgen, onder meer doordat de benadering van het conflict totaal ander is. De betrokkenen moeten, onder leiding van de mediator, zich open uitlaten tegenover elkaar en samen zoeken naar een oplossing.

De nalatenschapsmediator onderzoekt en bespreekt met partijen in een serie sessies alle spanningen en problemen en zoekt samen met de deelnemers naar de oorzaken. Dat gebeurt gezamenlijk, maar ook in een-op-eengesprekken (caucus). De mediator verheldert en analyseert samen met hen die oorzaken. Ook hier ontdekken partijen zelf welke mechanismen door bepaalde feiten, indrukken of gedachten in werking zijn getreden en waardoor over en weer reacties zijn gegeven die tot verwijdering hebben geleid. In talloze gevallen blijkt

De Koninklijke Notariële Beroepsorganisatie stelt o.m.: 'De KNB vindt mediation een interessant werkterrein voor het notariaat en stimuleert notarissen dit werkterrein te betreden. Wel benadrukt de KNB dat er goede kwaliteitseisen moeten komen voor mediators (...)', zie https://www.knb.nl/standpunten/mediation.

35 Steeds meer rechters leren zich mediationvaardigheden aan en hanteren dito technieken ter zitting. Zie ook bijzonder hoogleraar Mediation D. Alewijn, Tussen recht en vrede. Mediation in de responsieve rechtsstaat (oratie VU Amsterdam), Den Haag: Sdu Uitgevers 2018: 'De mediator helpt hen om een, voor beiden, aanvaardbare oplossing voor dit conflict te vinden. Daar kunnen rechters veel van leren, niet alleen omdat rechters graag zaken schikken, maar ook, omdat het innemen van een mediatorspositie helpt om partijen echt te horen.'

36 Zie de publicaties van B. Hellinger zoals o.m.: De verborgen dynamiek van familiebanden, Haarlem: Altamira 2015.

37 Met p.e.-punten van o.m. de KNB. http://www.epn-notaris.nl/wp-content/uploads/2016/02/Brochureopleiding-nalatenschapsmediation-2016-2017.pdf.

38 http://nalatenschapsmediation.com/register/ 
het te gaan om relatief kleine misverstanden, fouten en onhebbelijkheden die jaren hebben doorgewerkt. Daardoor zijn beelden ontstaan en is men door een negatieve bril naar de ander(en) gaan kijken: veel van de latere gedragingen en opmerkingen werden vervolgens in dat ongunstige daglicht uitgelegd, waardoor schier onoverbrugbare kloven leken te zijn ontstaan.

Voor wat betreft de juridische kant van het conflict bezit de nalatenschapsmediator de vereiste kennis om het juridische speelveld te bewaken en partijen te adviseren over de potentiële oplossingen die rechtens en/of fiscaal mogelijk zijn; zo nodig zal hij externe expertise inbrengen.

Door deze discussies onder leiding van de nalatenschapsmediator kunnen partijen hun vertrouwen in elkaar en hun verhoudingen herstellen en lossen zij het erfenisprobleem zelf op.

\section{Conclusie}

Anders dan Paul Scholten ten aanzien van het Burgerlijk Wetboek opmerkte, ${ }^{39}$ is het nieuwe erfrecht geen rustig bezit: de tijd noch het recht staan stil. 